\title{
A Dual-Targeting Ruthenium Nanodrug that Inhibits Primary Tumor Growth and Lung Metastasis by the PARP/ATM Pathway
}

Yu Lu

Capital Medical University

Di Zhu

Capital Medical University

Lin Gui

Capital Medical University

Yuanming Li

Peking Hospital

Wenjing Wang

Capital Medical University Youan Hospital

Jiawang Liu

University of Tennessee Health Science Center

Yuji Wang ( $\nabla$ wangyuji@ccmu.edu.cn )

Capital Medical University https://orcid.org/0000-0003-3842-7627

Research

Keywords: Nanodrug, dual-targeting, lung, metastasis

Posted Date: June 26th, 2020

DOl: https://doi.org/10.21203/rs.3.rs-36952/v1

License: (c) (i) This work is licensed under a Creative Commons Attribution 4.0 International License.

Read Full License 
Table 1. Stern-Volmer quenching constant $\left(\mathrm{K}_{\mathrm{sv}}, \mathrm{L} \cdot \mathrm{mol}^{-1}\right)$, biomolecular quenching rate constant $\left(K_{q}, \mathrm{~L}\right.$ $\left.\mathrm{mol}^{-1} \cdot \mathrm{s}^{-1}\right)$, binding constant $\left(K b, \mathrm{~L} \cdot \mathrm{mol}^{-1}\right)$ and the number of binding sites $(n)$ of Ru complexes and human transferrin.

\begin{tabular}{lllll}
\hline & $\mathrm{K}_{\mathrm{sv}}{ }^{*} 10^{5}$ & $K_{q}{ }^{*} 10^{13}$ & $n$ & $K_{b}{ }^{*} 10^{5}$ \\
\hline $\mathbf{2 b}$ & 1.09 & 1.89 & 1.1 & 3.97 \\
\hline
\end{tabular}


A

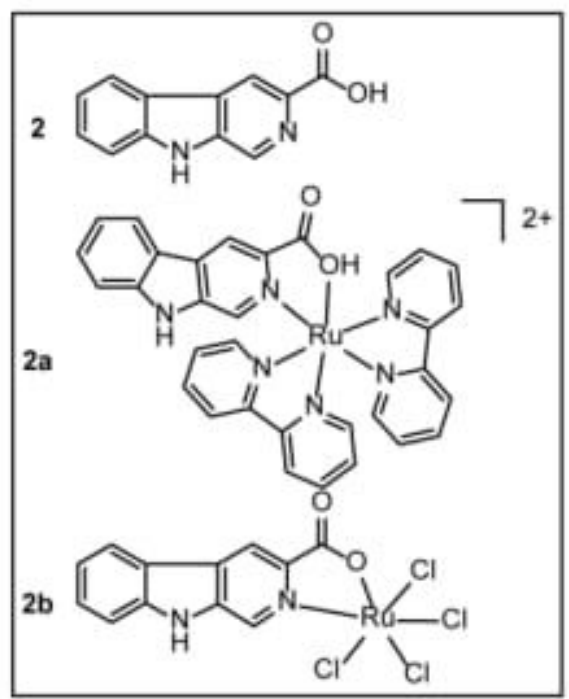

D
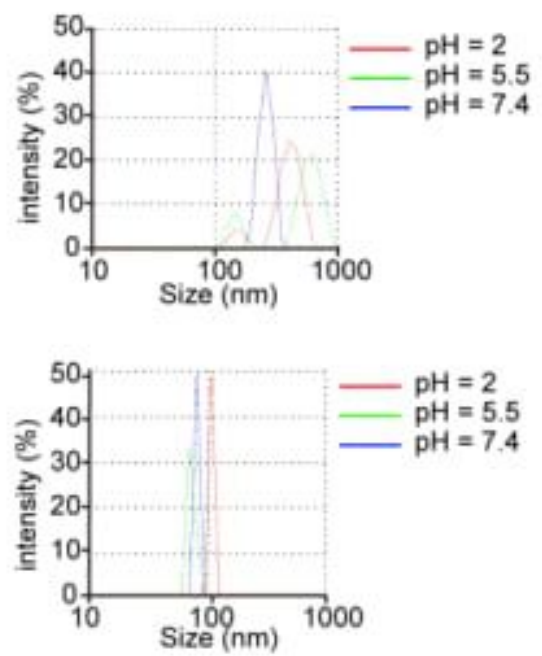

G

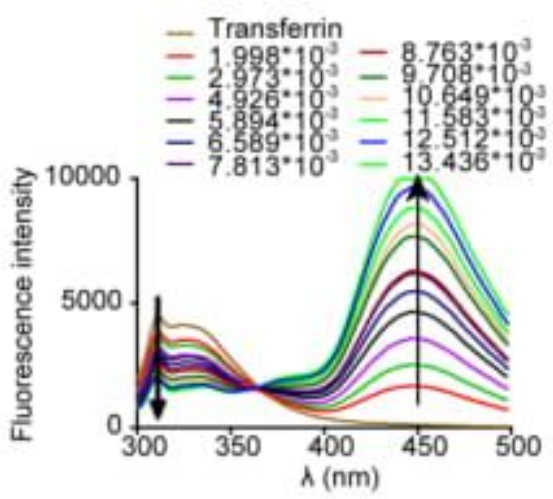

B
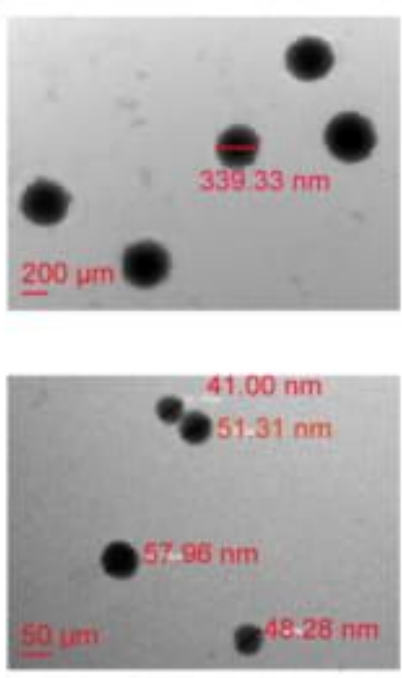

$\mathrm{E}$
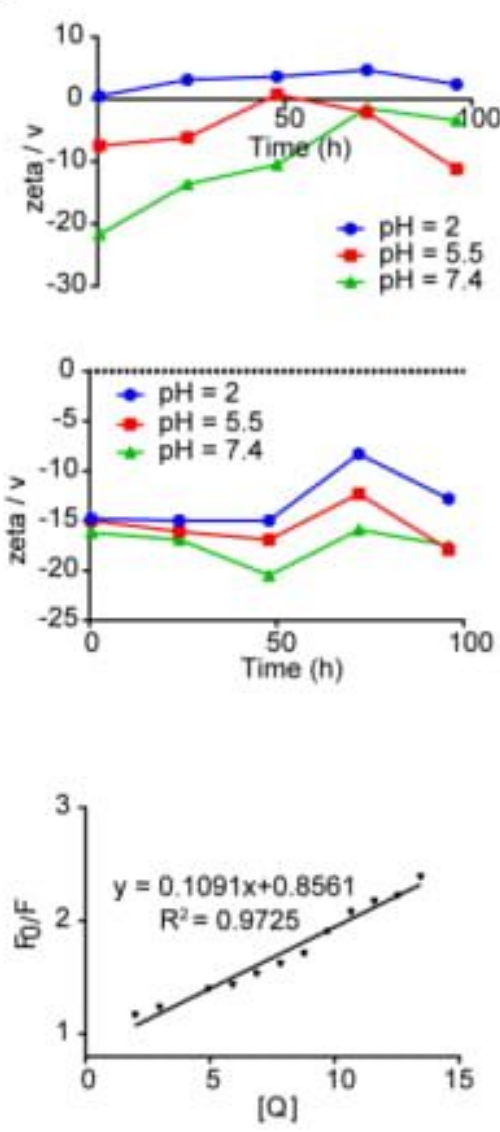

C
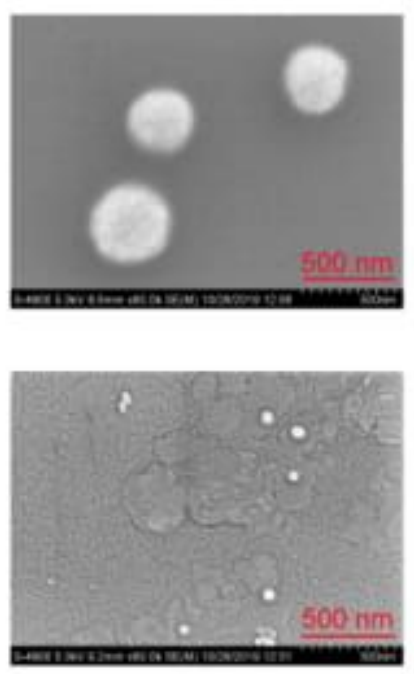

$\mathrm{F}$
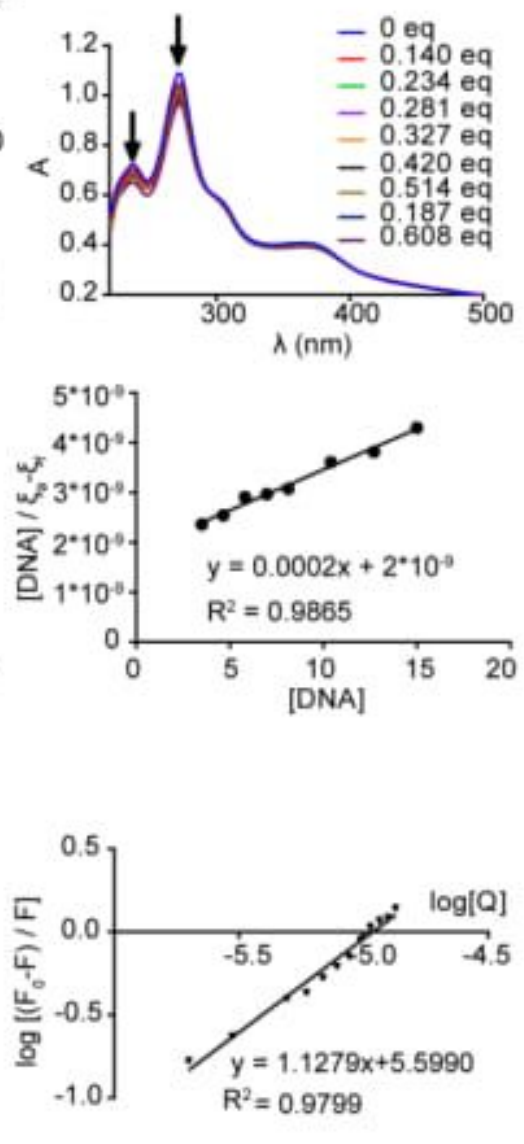

\section{Figure 1}

Physicochemical characterization of 2b. (A) Structure of 2, 2a and 2b. (B) TEM image of the Ru ligand 2 (up) and complex $2 b$ (down). (C) SEM image of the Ru ligand 2 (up) and complex 2b (down). (D) Size of 2 (up) and $2 \mathrm{~b}$ (down) at different pH values. (E) Zeta potentials of 2 (up) and $2 \mathrm{~b}$ (down) at different $\mathrm{pH}$ 
values within $96 \mathrm{~h}$ (detected at $0.5 \mathrm{~h}, 24 \mathrm{~h}, 48 \mathrm{~h}, 72 \mathrm{~h}$ and $96 \mathrm{~h}$ ). (F) UV spectra of $2 \mathrm{~b}$ with different concentrations of ctDNA. (G) Fluorescence emission spectra of hTF $(0.4 \mu \mathrm{M}, \lambda e x=280 \mathrm{~nm})$ with different concentrations of $2 \mathrm{~b}$. The classical Stern-Volmer equation and modified Stern-Volmer equation plots show tryptophan quenching in hTF.

A

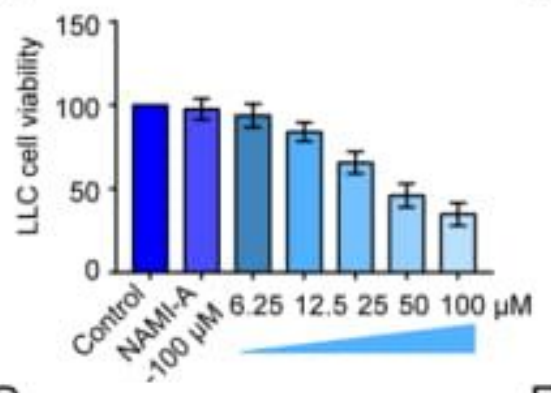

D

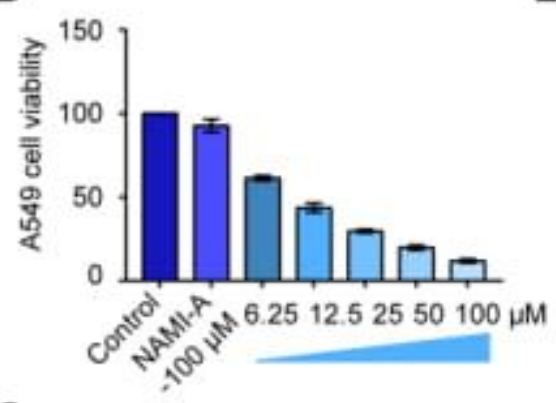

G

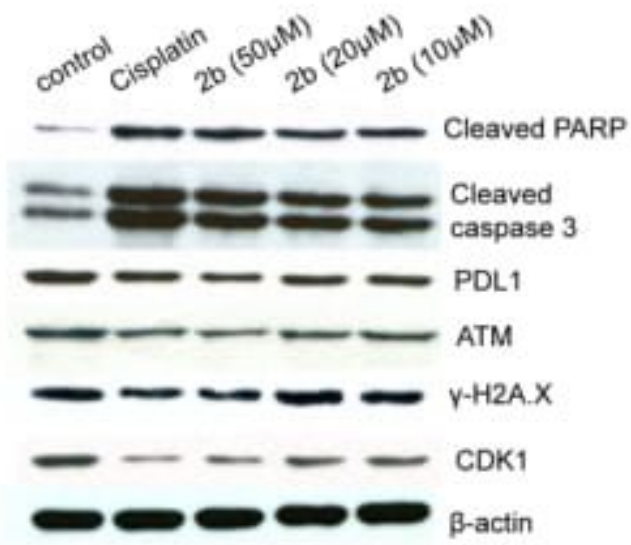

B

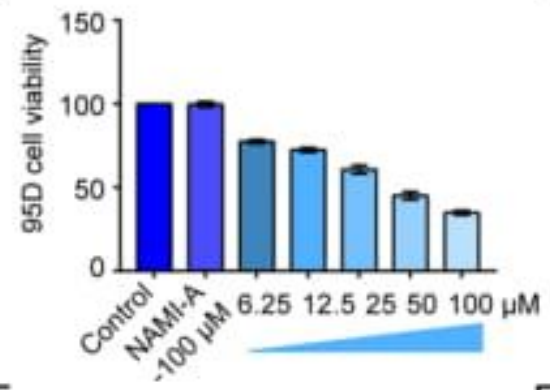

$E$

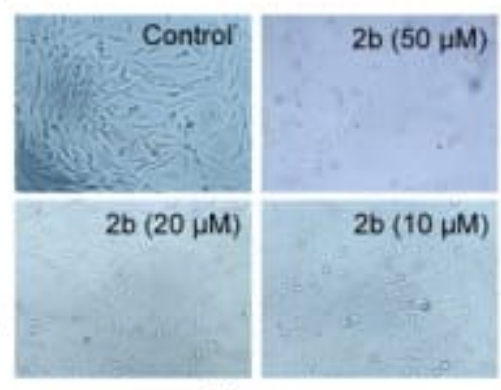

$\mathrm{H}$
$\mathrm{C}$

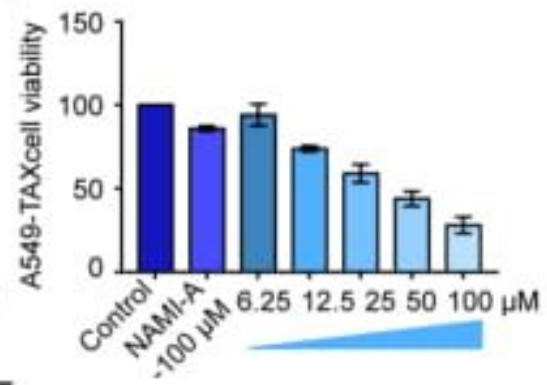

$\mathrm{F}$

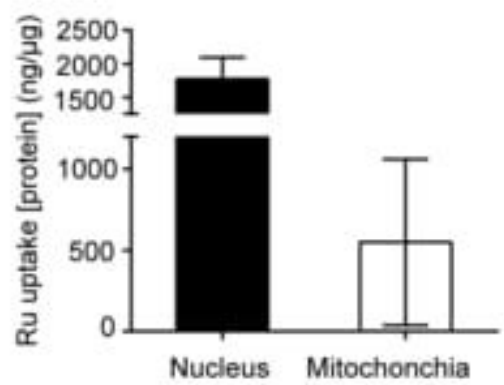

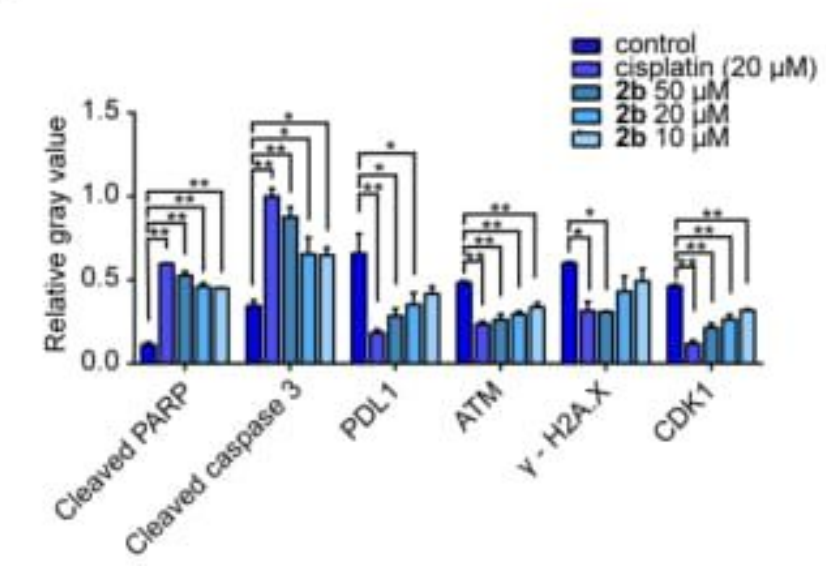

Figure 2

(A-D) Cell viability of LLC, 95D, A549-TAX and A549 cancer cells treated with different concentrations of $2 \mathrm{~b}$ and $100 \mu \mathrm{M}$ NAMI-A. The concentrations of $2 \mathrm{~b}$ were $6.25,12.5,25,50$, and $100 \mu \mathrm{M}$. (E) Morphological changes in cells in the control and administration groups incubated with $5 \% \mathrm{CO} 2$ at $37^{\circ} \mathrm{C}$ for $48 \mathrm{~h}$. (F) The intracellular uptake of Ru in the $20 \mu \mathrm{M}$ group. (G-H) Western blotting image and relative gray value analysis of proteins in $\mathrm{A} 549$ cells treated with $2 \mathrm{~b}$. 
A

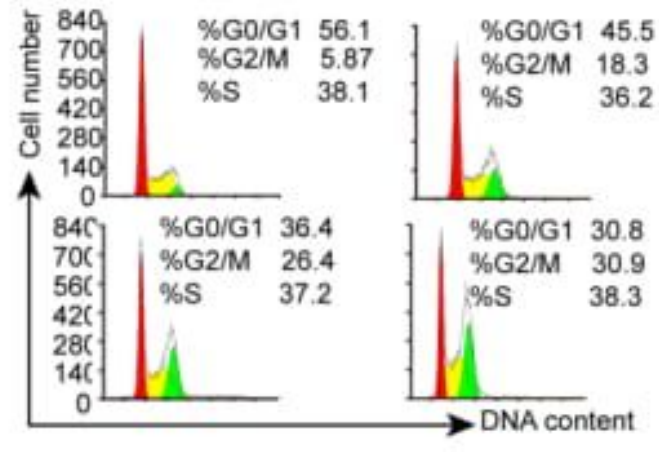

C

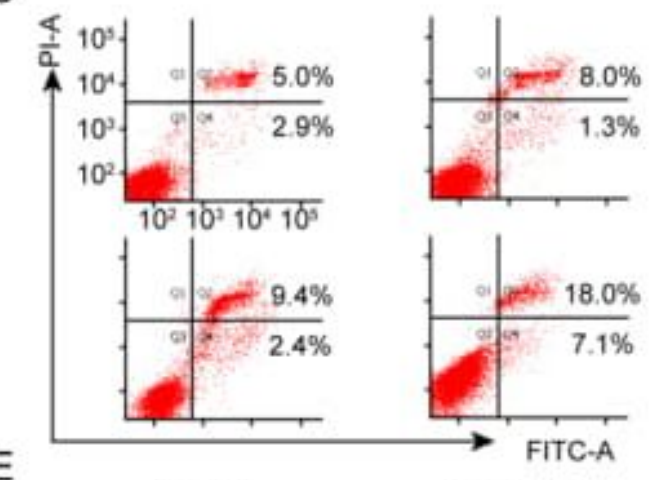

E
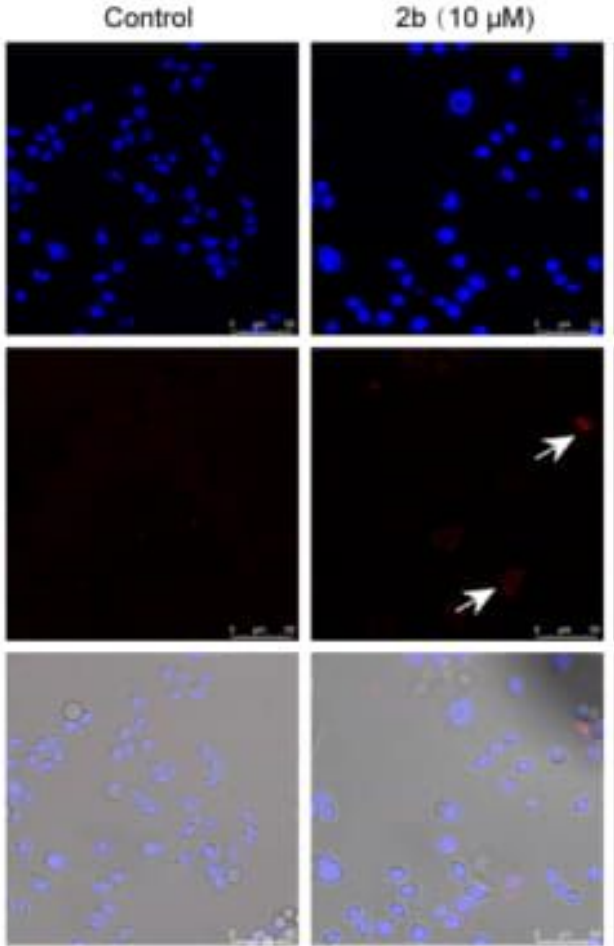

\section{B}

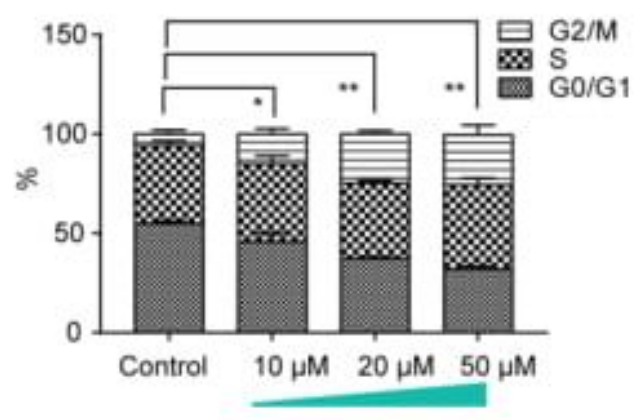

D

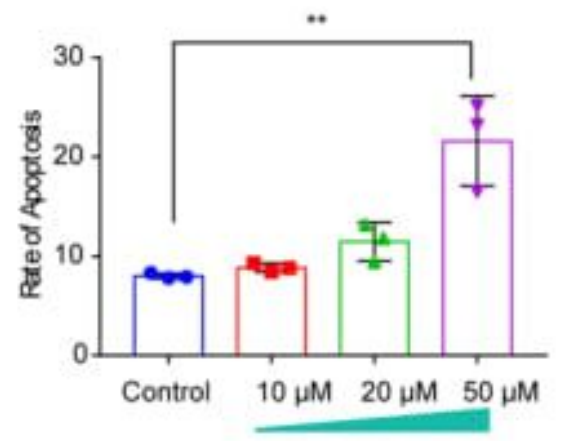

$2 \mathrm{~b}(20 \mu \mathrm{M})$
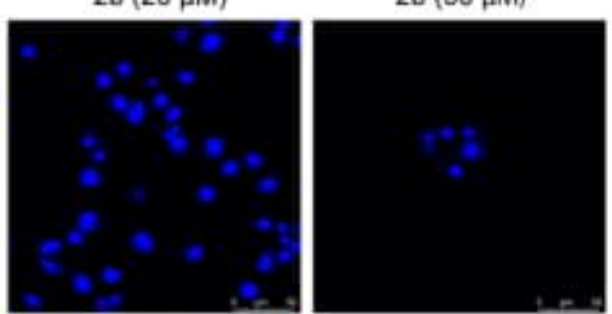

종
$\frac{9}{9}$
g
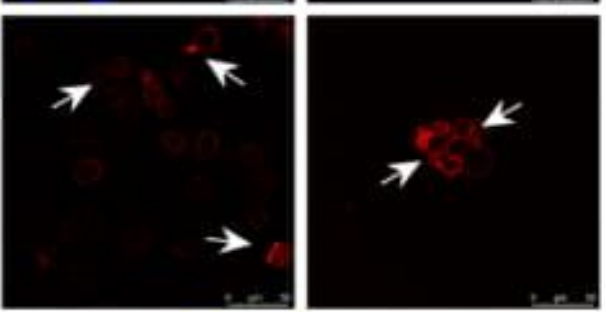

离

종

\section{Figure 3}

(A-B) Effect of $2 b$ on the cell cycle. (C-D) Effect of $2 b$ on cell apoptosis (Annexin V-FITC/PI, collected by flow cytometry). (E-F) Effect of 2b on cell apoptosis (Annexin V-PE/Hoechst, observed by confocal microscopy). 
A

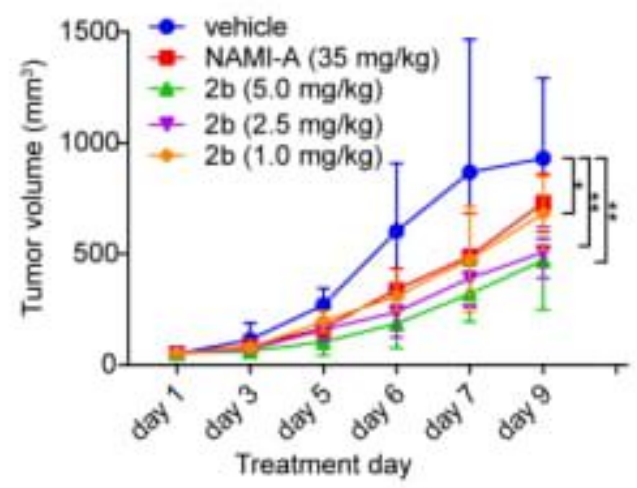

C

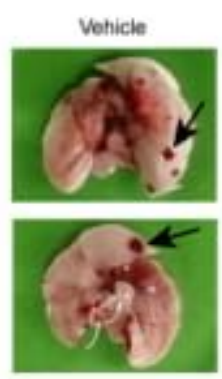

D
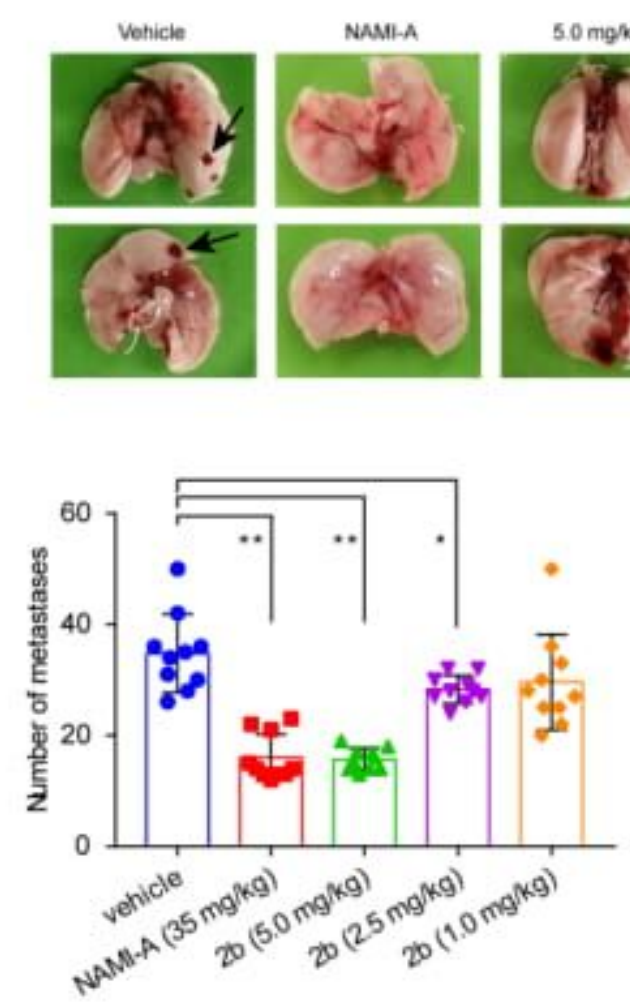

B
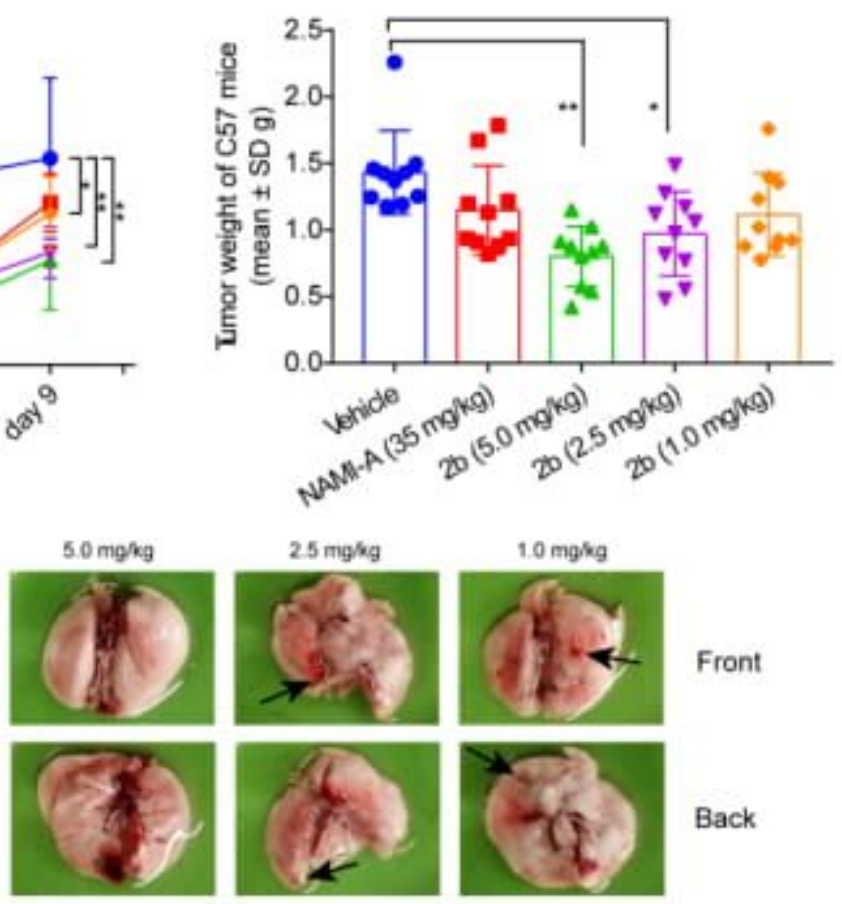

Front

Back

$\mathrm{E}$

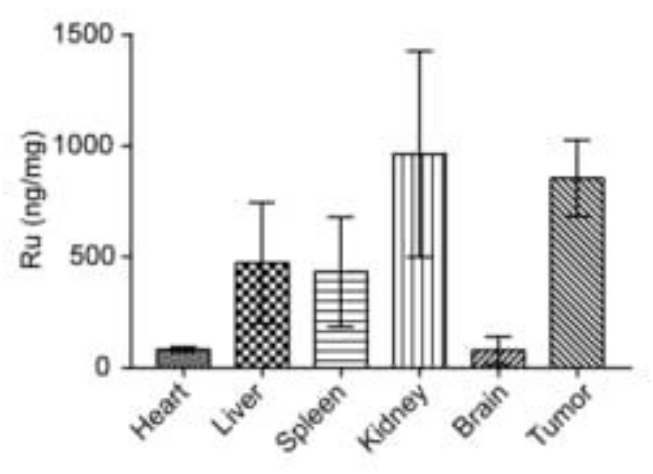

\section{Figure 4}

Effect of the Ru complex $2 \mathrm{~b}$ on LLC tumor growth and metastasis in C57BL/6 mice. (A) Dose-dependent volume curve of LLC tumors. (B) Tumor weight of treated C57BL/ 6 mice. (C) Representative images of metastasis in the lung. (D) The number of metastases. (E) Body distribution of $2 \mathrm{~b}(5.0 \mathrm{mg} / \mathrm{kg})$. It is represented by the mean $\pm S D(n g)$ of ruthenium per $g$ of organ, $n=6$. 
A

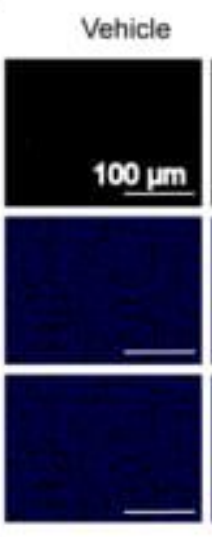

C

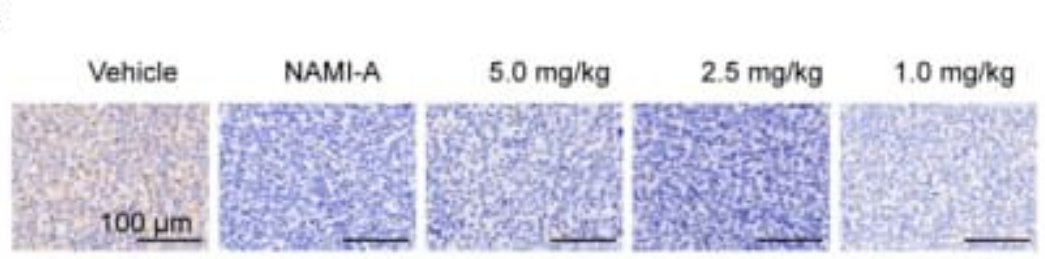

B

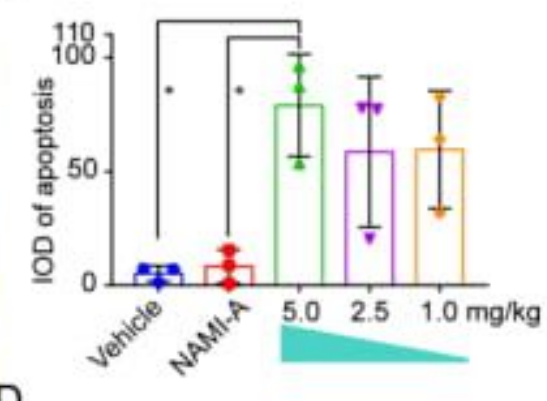

D

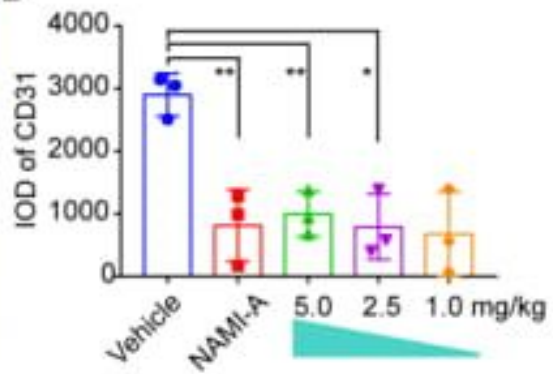

Figure 5

(A-B) Images and statistics of apoptosis tumor tissue apoptosis by TUNEL. (C-D) Image and statistics of CD31 expression in tumor tissue.

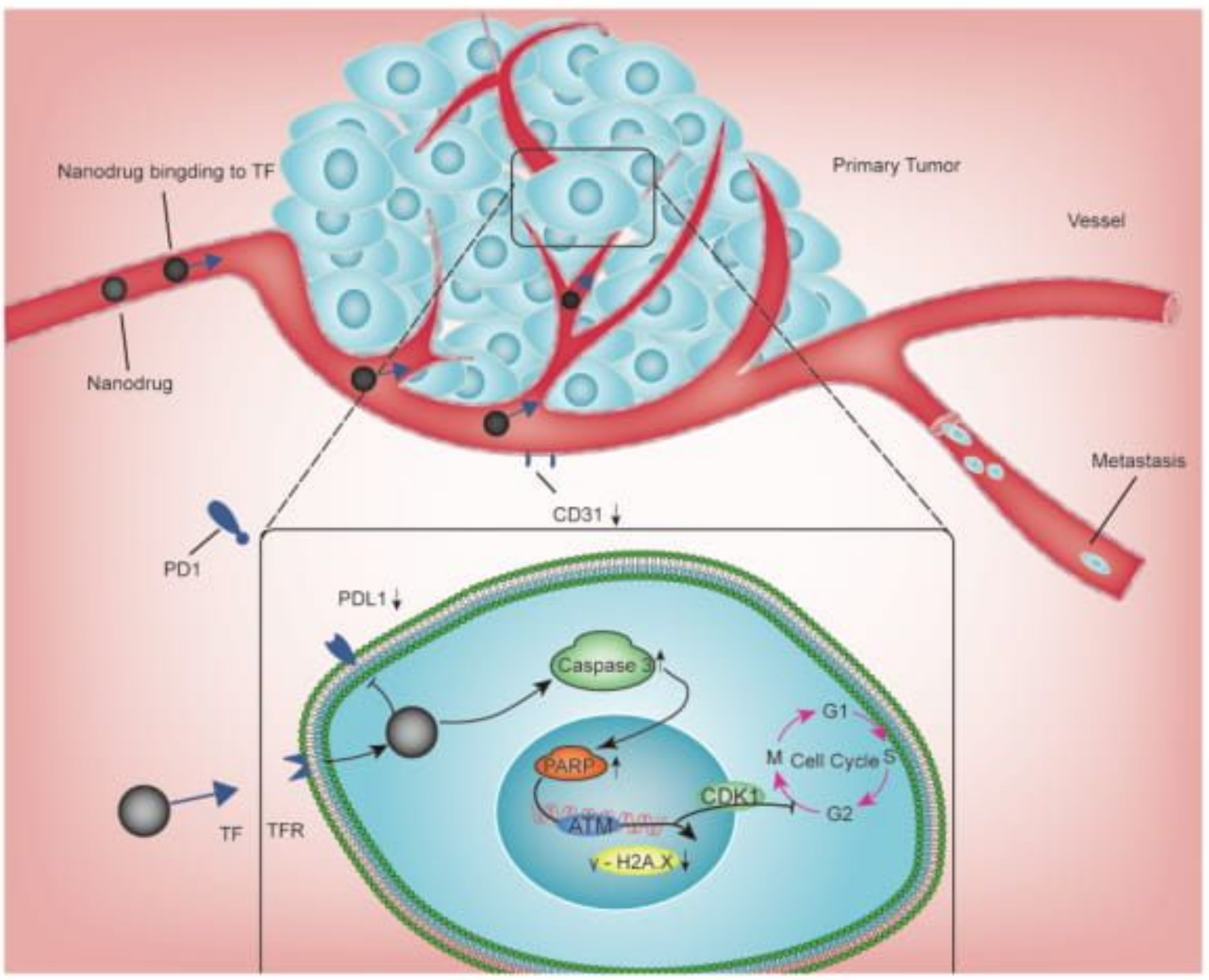


Figure 6

Mechanisms of complex 2b.

\section{Supplementary Files}

This is a list of supplementary files associated with this preprint. Click to download.

- 3personalcover.pdf

- 2supplementaryinformationluyu.pdf 